2. Коваль Л. В. Професійна підготовка майбутніх учителів початкової школи: технологічна складова: монографія / Л. В. Коваль. - Донецьк: Юго-Восток, 2009. - 375 с.

3. Крутій К. Освітній простір дошкільного навчального закладу: монографія: у 2 ч. Ч. 1 / К. Крутій. К.: Освіта, 2009. - 302 с.

4. Матвієнко О.В. Теоретико-методичні засади підготовки майбутніх учителів до педагогічної взаємодії у навчально-виховному середовищі школи першого ступеня: автореф. дис. ... д-ра пед. наук: 13.00.04 / О. В. Матвієнко. - К., 2010. - 36 с.

5. Пріма Р. М. Професійна мобільність майбутнього вчителя початкових класів: навчальнометодичний посібник / Р. М. Пріма. - Луцьк: Вета, 2007. - 128 с.

6. Цимбалару А. Д. Педагогічне проектування освітнього простору в школі 1 ступення: теорія $\mathrm{i}$ практика: монографія / А. Д. Цимбалару. - К.: Педагогічна думка, 2013. - 692 с.

7. Чайка В. М. Підготовка майбутнього вчителя до саморегуляції педагогічної діяльності: монографія; за ред. Г. В. Терещука / В. Чайка. - Тернопіль: ТНПУ, 2006. - 275 с.

\title{
REFERENCES
}

1. Basina A. Metodyka vykladannia inozemnoi movy v pochatkovii shkoli [Method of teaching foreign language in elementary school].A. Basina. K.. Shkilnyi svit, 2007. 128 s.

2. Koval L. V. Profesiyna pidhotovka maibutnikh uchyteliv pochatkovoi shkoly: tekhnolohichna skladova: monohrafiia [Professional training of future teachers of elementary school: technological component: monograph], L. V. Koval. Donetsk. Yuho-Vostok, 2009. 375 s.

3. Krutiy K. Osvitnii prostir doshkilnoho navchalnoho zakladu [Educational space of pre-school educational institution], monohrafiia u 2 ch. CH. 1. K. Krutiy. Kyiv, Osvita, 2009. 302 s.

4. Matviienko O. V. Teoretyko-metodychni zasady pidhotovky maibutnikh uchyteliv do pedahohichnoi vzaiemodii u navchalno-vykhovnomu seredovyshchi shkoly pershoho stupenya: avtoref. dys. na zdobuttya nauk. stupenia doktora ped. nauk: spets. 13.00.04 «Teoriia ta metodyka profesinoii osvity» [Theoretical and methodological principles of preparation of future teachers for pedagogical interaction in the educational-educational environment of the school of the first degree]. O. V. Matviwenko. Kyiv, 2010.36 s.

5. Prima R. M. Profesiina mobilnist maibutnoho vchytelia pochatkovykh klasiv: navchalno-metodychnyi posibnyk [Professional Mobility of the Future Teacher of Elementary Schools: A Methodological Manual]. R. M. Prima. Lutsk, Veta, 2007. 128 s.

6. Tsymbalaru A. D. Pedahohichne proektuvannia osvitnoho prostoru $\mathrm{v}$ shkoli 1 stupennia, teoriia $\mathrm{i}$ praktyka, monohrafiia [Pedagogical design of educational space in the school of the 1st stage, heory and practice: monograph]. A. D. Tsymbalaru. Kyiv, Pedahohichna dumka, 2013. $692 \mathrm{s.}$

7. Chayka V. M. Pidhotovka maibutnoho vchytelia do samorehuliatsii pedahohichnoi diialnosti: monohrafiia [Preparation of the future teacher for self-regulation of pedagogical activity: monograph]. Volodymyr Chayka, za red. H. V. Tereshchuka. Ternopil, TNPU, 2006. 275 s.

Стаття надійшла в редакиію 02.09.2017 p.

УАК 378.011.3-051:796]-027.21

DOI: 10:25128/2415-3605.17.3.6

ОКСАНА В'Я $А$ А

oksnv@ukr.net викладач,

Національний педагогічний університет імені М. П. Драгоманова м. Київ, вул. Пирогова, 9

\section{СЕРГІЙ ПУТРОВ}

sergiy_putrov@ukr.net доктор філософських наук, доцент, Національний педагогічний університет імені М. П. Драгоманова м. Київ, вул. Пирогова, 9 


\title{
ПРОФЕСІЙНА ОСВІТА
}

\section{СУТНІСТЬ ФОРМУВАННЯ ГОТОВНОСТІ МАЙБУТНІХ УЧИТЕАІВ ФІЗИЧНОЇ КУАЬТУРИ АО ПРОФЕСІЙНОЇ САМОРЕААІЗАЦІЇ В ОЗАОРОВЧІЙ АІЯАЬНОСТІ}

\begin{abstract}
Вказано, щзо сочүіально-економічні перетворення, які відбуваються в намій країні та інтеграція України в єдиний європейський освітній простір орієнтують на якісно новий рівень професійної підготовки майбутніх учителів фізичної культури у ВНЗ. Формування готовності майбутніх учителів фізичної культури до професійної самореалізації в оздоровчій діяльності розглянуто як процес набуття студентами кваліфікації, щзо забезпечить їм ефективну реалізацію власних здібностей, розкриття свого творчого потенціалу, оволодіння певним сочіальним досвідом, підвищення професійної майстерності та удосконалення в професії, спрямованої на залучення учнів до занять фізичними вправами на уроках фізичної культури, при проведенні фізкультурно-оздоровчих заходів у режимі навчального дня, позакласної та позашкільної фізкультурно-оздоровчої роботи. Зазначено, щзо вища школа активно шукає відповіді на питання, які поставила сучасна дійсність, та на питання, пов'язані із збереженням $i$ зміцненням здоров'я учасників освітнього процесу. Акцентовано увагу на тому, щуо вчителі фізичної культури покликані вирішувати складні завдання фізичного виховання молоді, прилучення дітей та юнацтва до занять фізичною культурою $і$ спортом. Показано, щчо оздоровча діяльність є однією 3 необхідних умов розгортання процесу самореалізації майбутнього вчителя фізичної культури, здатного спрямувати свої зусилля на зміџнення та збереження здоров'я учнів загальноосвітніх навчальних закладів.
\end{abstract}

Ключові слова: формування готовності, майбутні вчителі фізичної культури, професійна самореалізачія, оздоровча діяльність.

ОКСАНА ВЯААЯ

oksnv@ukr.net преподаватель, Национальный педагогический университет имени М. П. Драгоманова м. Киев, вул. Пирогова, 9

\section{СЕРГЕЙ ПУТРОВ}

sergiy_putrov@ukr.net доктор философских наук, доцент, Национальный педагогический университет имени М. П. Драгоманова м. Киев, вул. Пирогова, 9

\section{СУЩНОСТЬ ФОРМИРОВАНИЯ ГОТОВНОСТИ БУАУЩИХ УЧИТЕАЕЙ ФИЗИЧЕСКОЙ КУАЬТУРЫ К ПРОФЕССИОНААЬНОЙ САМОРЕААИЗАЦИИ В ОЗАОРОВИТЕАЬНОЙ АЕЯТЕАЬНОСТИ}

Указано, что соччиально-экономические преобразования, происходящчие в нашей стране и интеграция Украины в единое европейское образовательное пространство ориентируют на качественно новый уровень профессиональной подготовки будущих учителей физической культуры в вузах. Формирование готовности будущих учителей физической культуры к профессиональной самореализации в оздоровительной деятельности рассмотрено как прочесс приобретения студентами квалификации, которая обеспечит им эффективную реализацию собственных способностей, раскрытие своего творческого потенциала, овладение определенным сочиальным опытом, повымение профессионального мастерства и совершенствование в профессии, направленной на привлечение учеников к занятиям физическими упражнениями на уроках физической культуры, при проведении физкультурно-оздоровительных мероприятий в режиме учебного дня, внеклассной и внешкольной физкультурно-оздоровительной работьл. Отмечено, что высшая школа активно ищет ответь на вопросы, которые поставила современная действительность, и на вопросы, связанные с сохранением и укреплением здоровья участников образовательного процесса. Акцентировано внимание на том, что учителя физической культуры призваны решать сложные задачи физического воспитания молодежи, приобщения детей и юношества к занятиям физической культурой и спортом. Подчеркнуто, что оздоровительная деятельность является одним из необходимых условий развертывания процесса самореализащии будущего учителя физической культуры, способного направить свои усилия на укрепление и сохранение здоровья учащчихся общеобразовательных учебных заведений. 
Ключевые слова: формирование готовности, будущзие учителя физической культуры, профессиональная самореализаџия, оздоровительная деятельность.

OKSANA VYALA

oksnv@ukr.net

The Lecture,

National Pedagogical Dragomanov University

Pirogova str. 9, Kyiv

SERGIY PUTROV

sergiy_putrov@ukr.net

Doctor of Philosophy Science, Associate Professor,

National Pedagogical Dragomanov University

Pirogova str. 9, Kyiv

\section{THE ESSENCE OF THE FORMATION OF THE READINESS OF THE FUTURE TEACHERS OF PHYSICAL EDUCATION FOR THE PROFESSIONAL SELF- REALIZATION IN HEALTH-IMPROVING ACTIVITIES}

The issues of the professional self-realization in health-improving activities are relevant in the current conditions of the European integration of educational systems and improving the efficiency of the training of the future teachers of physical education in higher educational establishments. The integration of Ukraine into the world system of higher education is aimed at reconsidering the main directions of the training of the future teachers of physical education in higher educational establishments. The formation of the readiness of the future teachers of physical education for professional self-realization in health-improving activity is considered as process of acquiring skills by students, which will ensure the effective implementation of their abilities, the manifestation of their creativity and mastering certain social experience, enhancing professional skills and improvment in the profession with the purpose of the involvement of pupils in physical exercises at the lessons of physical education, and carrying out sports-improving actions during the day, out-of-class and out-of-school physical culture and health-improvement work. It is noted that higher school is actively seeking answers to the questions posed by the present-day reality, and to questions related to the preservation and strengthening of the health of participants in the educational process. The need for the program for the modernization of higher physical education is determined by the internal patterns of the development of higher education and the longterm development needs of the individual, the society and the state that have developed in the system of professional training of future physical education teachers in higher education institutions on the basis of preserving and multiplying the best traditions of domestic and world experience. Attention is focused on the fact that the teachers of physical education are called upon to solve the complex tasks of physical education of the youth, to involve children and young people in physical culture and sports.

Keywords: the formation of readiness, the future teachers of physical education, professional selfrealization, health-improving activity.

Питання професійної самореалізації в оздоровчій діяльності $є$ актуальними в сучасних умовах європейської інтеграції освітніх систем та підвищення ефективності підготовки майбутніх учителів фізичної культури у ВНЗ. Інтеграція України зі світовою системою вищої освіти спрямована, зокрема, і на переосмислення основних напрямів професійної підготовки майбутніх учителів фізичної культури.

Тенденції розвитку сучасної освіти - гуманізація, інтеграція, диференціація, інтенсифікація і зростаючий обсяг інформації визначають модернізацію теоретичних основ адаптаційних механізмів соціалізації, а також виховання і навчання учнів, які за станом здоров'я належать до спеціальної медичної групи. Тому доречним 3 позицій сьогодення $є$ дослідження формування готовності майбутніх учителів фізичної культури до професійної самореалізації в оздоровчій діяльності.

Вітчизняні вчені О. Ю. Ажиппо, П. Б. Джуринський, Є. А. Захаріна, Л. І. Іванова, В. Г. Омельяненко, Л. П. Сущенко, О. В. Тимошенко, Б. М. Шиян та інші акцентували увагу на грунтовному розкриттю теоретичних і методичних засад професійної підготовки майбутніх учителів фізичної культури у ВНЗ. 
Професійна підготовка майбутніх учителів фізичної культури до різних видів фахової діяльності була предметом розвідок науковців. Ними досліджено підготовку майбутніх учителів фізичної культури до: позакласної виховної роботи у старшій школі (Л. П. Арефьєва); застосування інформаційних технологій у професійній діяльності (Г. Р. Генсерук); формування готовності до професійної діяльності майбутніх учителів фізичної культури (М. Т. Данилко); виховання здорового способу життя молодших школярів на засадах гендерного підходу (А. В. Заікін); формування моральних якостей молодших школярів (С. О. Ігнатенко); викладання основ безпеки життєдіяльності в загальноосвітній школі (Г. Д. Кондрацька); реалізації міжпредметних зв'язків у процесі фізичного виховання молодших школярів (О. Я. Кругляк); позакласної роботи 3 учнями основної школи (О. А. Стасенко); самовдосконалення та формування основ здорового способу життя (I. В. Шаповалова).

Мета статті - охарактеризувати сутність формування готовності майбутніх учителів фізичної культури до професійної самореалізації в оздоровчій діяльності.

Л. П. Арефьєва [1], Д. В. Бермудес [2], Н. Г. Денисенко [4], С. О. Ігнатенко [5], О. А. Стасенко [10] та інші спрямовують свої зусилля на тлумачення понять, які характеризують підготовку майбутніх учителів фізичної культури до здійснення різних видів професійної діяльності у загальноосвітніх навчальних закладах. Так, на підставі теоретичного аналізу літератури і власного досвіду Л. П. Арефьєва тлумачить поняття «підготовка майбутніх учителів фізичної культури до позакласної виховної роботи у старшій школі» як «процес оволодіння студентами сукупністю спеціальних знань, умінь і навичок, якостей, трудового досвіду і норм поведінки, які забезпечують успішну різноманітну фізкультурно-оздоровчу роботу, спрямовану на задоволення інтересів і запитів старшокласників щодо зміцнення іх здоров’я та організовану в позаурочний час» [1, с. 9].

Д. В. Бермудес трактує поняття «підготовка майбутніх учителів фізичної культури до реалізації варіативних модулів у процесі професійної діяльності» як цілеспрямований навчально-виховний процес у ВНЗ, що забезпечує професійну спрямованість (сукупність форм, методів і прийомів виховної діяльності) та спрямований на формування спеціальних знань, умінь і навичок, формує професійну готовність до реалізації засобів фізичної культури в загальноосвітніх навчальних закладах 3 урахуванням сучасних вимог діючої навчальної програми «Фізична культура. 5-11 класи» [2, с. 202].

Н. Г. Денисенко тлумачить поняття «підготовка майбутніх учителів фізичної культури до оздоровчої роботи 3 молодшими школярами» як «навчально-виховний процес, який відбувається у вищих навчальних закладах I-II рівня акредитації з метою набуття студентами кваліфікації, яка дозволить їм успішно працювати у початковій школі та формувати здоровий спосіб життя і життєво важливі рухові вміння та навички учнів молодшого шкільного віку, сприяти фізичному розвитку і підвищенню працездатності молодших школярів, самостійному та свідомому виконанню ними фізичних вправ у режимі дня, усвідомленню необхідності удосконалення основних якостей фізичного розвитку» $[4$, с. 9].

С. О. Ігнатенко визначає поняття «професійно-педагогічна підготовка майбутніх учителів фізичної культури» як «сукупність знань, вмінь і навичок, оволодіння якими дає змогу працювати вчителем у школі, а також формування психологічних i моральних якостей особистості вчителя фізичного виховання, важливих для визначення характеру мети і завдань його педагогічної діяльності» [5, с. 6].

О. А. Стасенко розглядає поняття «підготовка майбутніх учителів фізичної культури до позакласної роботи 3 учнями основної школи» як «процес, що спрямований на формування мотивацій (усвідомлення важливості позакласних занять фізичними вправами 3 учнями основної школи, зацікавленість цією роботою; бажання досягнути успіху в майбутній професійній діяльності, підвищення рівня професійної підготовленості та фахової кваліфікації), знань (особливостей організації та проведення позакласної роботи з учнями основної школи, методики лікарсько-педагогічного контролю за навчально-тренувальним процесом, особистісно-орієнтованих технологій фізичного розвитку учнів основної школи, обізнаність зі способами спрямування діяльності колективу фізичної культури школи й наданні повсякденної допомоги в його роботі), умінь (вдало організовувати навчальнотренувальний процес у масовому спорті, планувати позакласну роботу з учнями основної школи, якісно проводити всі форми позакласних занять, надавати допомогу учням щодо 
самостійних занять фізичними вправами, систематично здійснювати самоаналіз професійної діяльності), навичок та особистісних якостей майбутніх учителів фізичної культури (навичок комунікативної і творчої діяльності)» [10, с. 151].

Нами формування готовності майбутніх учителів фізичної культури до професійної самореалізації в оздоровчій діяльності розглядається як процес набуття студентами кваліфікації, що забезпечить їм ефективну реалізацію власних здібностей, розкриття свого творчого потенціалу, оволодіння певним соціальним досвідом, підвищення професійної майстерності та удосконалення в професії, спрямованої на залучення учнів до занять фізичними вправами на уроках фізичної культури, при проведенні фізкультурно-оздоровчих заходів у режимі навчального дня, позакласної та позашкільної фізкультурно-оздоровчої роботи.

Професійна самореалізація майбутніх учителів фізичної культури в процесі навчання у ВНЗ має свою специфіку. В студентські роки відбувається становлення особистості, іiі саморозвиток і формування цілісного «Я». Професійна самореалізація особистості майбутніх учителів фізичної культури пов'язана з прагненням стати кращим професійно та особистісно.

Основні підходи до розуміння самореалізації особистості відображено у філософській, психологічній i педагогічній науках і визначається: по-перше, як реалізація особистістю сутнісних сил або людської природи; по-друге, як максимальне розкриття творчого потенціалу особистості; по-трете, як якнайповніше використання іiі здібностей і можливостей в прагненні розкрити себе 3 відчуттям повноти життя. Так, у філософському аспекті самореалізація $є$ свідомим процесом опредмечування сутнісних сил людини у взаємодії індивідів 3 соціокультурною дійсністю, який може набувати форми творення об'єктів матеріальної та духовної культури, усе різноманіття соціальної діяльності. Психологічний аспект дослідження припускає розуміння самореалізації як елементу мотиваційної сфери, що відноситься до вищих потреб людини, і як психологічної основи діяльності та іiі об'єктивний і суб'єктивний результат. У педагогіці самореалізація визначається однією з цілей освіти і полягає в допомозі особистості в здійсненні позитивних можливостей та розкритті здібностей.

До основних видів прояву самореалізації особистості М. Г. Ватковська відносять: діяльнісну самореалізацію, соціальну самореалізацію та особистісну самореалізацію [3, с. 5]. На думку вченої, «діяльнісна самореалізація суб'єкта характеризується самовираженням у різних видах діяльності й забезпечує високий рівень професійної компетенції» [3, с. 5]. Соціальна самореалізація пов'язана з виконанням гуманітарної місії, суспільно-господарською, суспільнополітичною, суспільно-освітньою або будь-якою іншою громадсько-корисною діяльністю. Особистісна самореалізація сприяє духовному зростанню людини, забезпечуючи на перших етапах розвиток особистісного потенціалу: відповідальності, допитливості, товариськості, працьовитості, наполегливості, ініціативності, ерудиції, креативності, моральності тощо.

Під особистісною самореалізацією О. П. Савчук розуміє «знайдення, пізнання себе, і як наслідок цього, розвиток своїх особистісних можливостей та здібностей, зусиль у професійній діяльності, співтворчості, взаємодії, співдіяльності з іншими учасниками навчального процесу, збагачення особистісних та професійних сенсів діяльності і поведінки, задоволення спектру потреб, розкриття і посилення свободи індивідуального розвитку і творчості» [9, с. 154].

В. I. Муляр зазначає, що самореалізація «спрямована на розкриття саме гуманістичної, загальнолюдської сутності особистості, відповідних культурних цінностей, то для неї ступінь зрілості життєвої програми визначається, насамперед, співпаданням індивідуальної та суспільної значущості останньої, тим, наскільки широко і повно відображаються в ній загальнолюдські ідеали і особистісний смисл» [7, с. 150].

Саме в самореалізації проявляються, на думку О. Коропецької, «унікальність і глибина людської особистості, цілісність, збалансованість і гармонійність розвитку різних їі сторін, здійснюються можливості розвитку «Я» особистості, розкриваються i реалізуються іï екзистенційні потреби» [6, с. 156]. Ми погоджуємося з цією думкою. О. Коропецька вважає, що «продуктивне ставлення до світу передбачає здатність людини гармонійно поєднувати в собі як уміння репродуктивно сприймати світ, так і здатність до генеративного перетворення світу, його збагачення й оживлення за рахунок спонтанної активності своїх розумових й емоційних сил» [6, с. 157]. На думку вченої, «задоволення екзистенційних потреб людини в різних варіантах i модифікаціях 3 неповторними суб'єктивними й об'єктивними умовами іiі 
унікального життя приводять до самореалізації, яка в кожної людини індивідуальна, що відповідає лише їй і ії способу буття» [6, с. 162].

Теоретичний аналіз наукової літератури свідчить про відсутність загальноприйнятого визначення поняття «професійна самореалізація». Це поняття тлумачать як: «соціалізований шлях гармонійного розвитку особистості, поєднаний із здобуттям професійно-практичного та духовного досвіду в процесі отримання кваліфікації спеціаліста в період первинного професійного становлення (навчання у вищій школі) та вдосконалення фахового зростання в процесі виконання професійних ролей і обов'язків, що є невід'ємним атрибутом розкриття i здійснення особистісного професійного потенціалу» (О. І. Артемова); «розкриття якостей, можливостей, здібностей та досягнення максимуму потенціалу в професійній діяльності» (В. А. Лісовий); складний організований та багатоетапний процес поступового перетворення професійного потенційного на реальне шляхом залучення до професійних відносин, що відбувається протягом усього життя особистості (П. Ю. Семенухін); як «сукупність прояву індивідуальних професійно-особистісних якостей і властивостей фахівця, внаслідок чого він відтворює себе у своїй сутності в багатовимірній практичній та професійній діяльності» (Н. Є. Тимошенко).

Однією із важливих якостей професійної самореалізації вчителя фізичної культури є творчість.

Аналіз філософської та психолого-педагогічної літератури та їі осмислення дозволив Ю. П. Ненько запропонувати наступний підхід до визначення творчої особистості. Науковець визначає поняття «творча особистість» як «креативну особистість (особистість, що має внутрішні передумови творчої активності), яка внаслідок впливу зовнішніх факторів набула необхідних для актуалізації творчого потенціалу людини додаткових мотивів, особистісних утворень, здібностей, що сприяють дослідженню творчих результатів в одному чи кількох видах творчої діяльності [8, с. 250].

Нами було проведено анкетування 95 майбутніх учителів фізичної культури, які навчаються у Національному педагогічному університету імені М.П. Драгоманова. Позитивним в опитуванні студентів $є$ те, що 58,95 \% респондентів вважають за доцільне формувати їх готовність до професійної самореалізації в оздоровчій діяльності, 7,37 \% вважають це недоцільним, 33,68 \% опитаних студентів важко було відповісти на це питання (рис. 1).

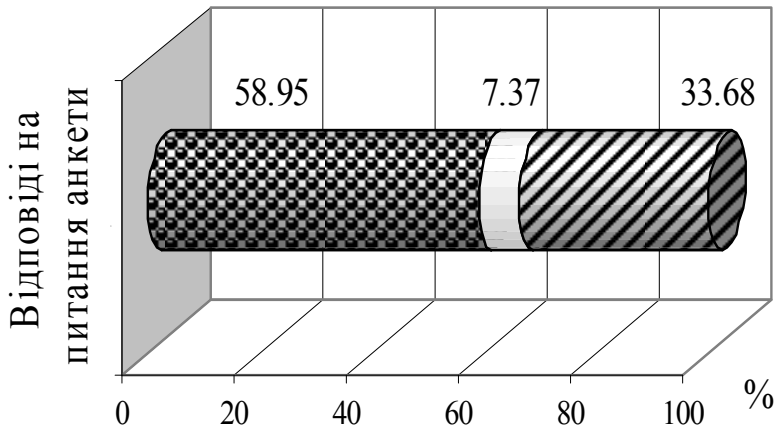

\section{Примітки:}

图 Вважають це доцільним

$\square$ Вважають це не доцільним

曰 Важко було відповісти

Рис. 1. Результати анкетування щодо формування у ВНЗ готовності майбутніх учителів фізичної культури до професійної самореалізачї в оздоровчій діяльності (\%).

Незначна частина опитаних студентів, а саме 14,74 \%, володіють термінологією, необхідною для професійної самореалізації в оздоровчій діяльності, 44,21 \% респондентів частково володіють цією термінологією, а 31,58 \% опитаних студентів не володіють. Відповідь «важко відповісти» обрали 9,47 \% респондентів (рис. 2). 


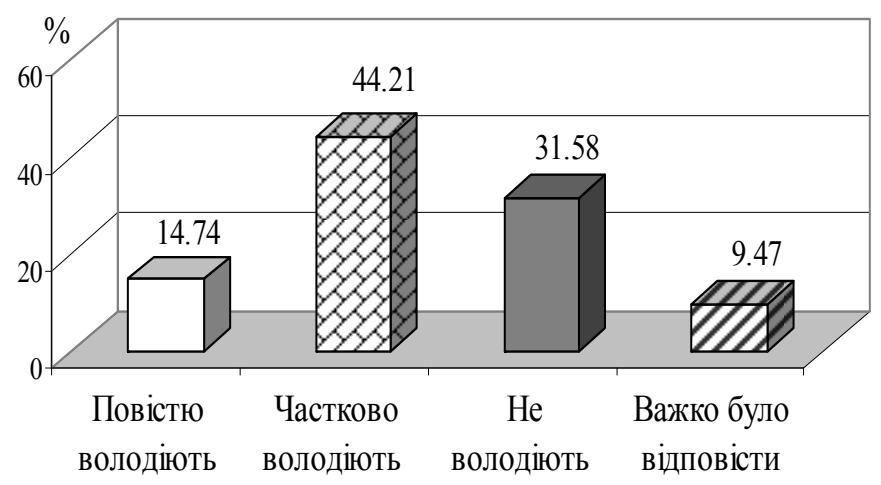

Відповіді на питання анкети

Рис. 2. Результати анкетування майбутніх учителів фізичної культури щодо володіння термінологією, необхідною для професійної самореалізації в оздоровчій діяльності (\%).

Варто вказати на зв'язок професійної самореалізації та професійного самовдосконалення. Основні функції готовності до професійного самовдосконалення, на думку І. В. Шаповалової, зводяться до таких: 1) діагностична - передбачає визначення нахилів та здібностей, виявлення рівня їх підготовленості та індивідуально-психологічних особливостей $з$ метою забезпечення ефективності підвищення кваліфікації; 2) компенсаторна - пов'язана з ліквідацією прогалин в освіті, зумовлених недоотриманням знань майбутніх учителів фізичної культури, застарінням раніше здобутих знань, необхідністю більш глибокого оволодіння предметно-професійними та педагогічними знаннями й уміннями; 3) адаптаційна - розвиток інформаційної культури, навчання, самоосвіти, основ педагогічного менеджменту з метою орієнтації в діяльності; 4) пізнавальна - забезпечує задоволення інформаційних, професійних та інтелектуальних потреб особистості; 5) прогностична - розкриває творчий потенціал, виявляє їх можливості й готовність до професійно-педагогічної діяльності [11, с. 433].

Таким чином, нині вища фізкультурна освіта, як складова частина системи вищої освіти України, виконує актуальне завдання кадрового забезпечення галузі фізичної культури та спорту. Необхідність програми модернізації вищої фізкультурної освіти визначається внутрішніми закономірностями розвитку вищої освіти і перспективними потребами розвитку особистості, суспільства і держави, що склалися в системі професійної підготовки майбутніх учителів фізичної культури у ВНЗ на основі збереження і примноження кращих традицій вітчизняного та світового досвіду. Готовність майбутніх учителів фізичної культури до професійної самореалізації в оздоровчій діяльності розглядається як інтегративне динамічне особистісне утворення, що визначає налаштованість на вирішення педагогічних завдань, пов'язаних зі зміцненням і збереженням здоров'я учнів, підвищення їх рухової активності та рівня фізичного розвитку.

Перспективи подальших досліджень вбачаємо у розробленні моделі формування готовності майбутніх учителів фізичної культури до професійної самореалізації в оздоровчій діяльності.

\section{ЛІТЕРАТУРА}

1. Арефьєва Л. П. Підготовка майбутніх учителів фізичної культури до позакласної виховної роботи у старшій школі: автореф. дис. ... канд. пед. наук: 13.00.04 / Л. П. Арефьєва. - К., 2010. - 22 с.

2. Бермудес Д. В. Підготовка майбутніх учителів фізичної культури до реалізації варіативних модулів у процесі професійної діяльності / Д. В. Бермудес // Вісник Чернігівського національного педагогічного університету. Серія: Педагогічні науки. - 2016. - Вип. 137. - С. 200-203.

3. Ватковська М. Г. Самореалізація особистості в постіндустріальному суспільстві / М. Г. Ватковська // Вісник Національної академії керівних кадрів культури і мистецтв. - 2014. - № 3. - С. 3-8.

4. Денисенко Н. Г. Підготовка майбутніх учителів фізичної культури до оздоровчої роботи з молодшими школярами: автореф. дис. ... канд. пед. наук: 13.00 .04 / Н. Г. Денисенко. - К., 2011. - 22 с.

5. Ігнатенко С. О. Підготовка майбутніх учителів фізичного виховання до формування моральних якостей молодших школярів: автореф. дис. ... канд. пед. наук: 13.00 .04 / С. О. Ігнатенко. - Одеса, 2007. $-21 \mathrm{c}$. 
6. Коропецька О. Самореалізація як екзистенційна потреба особистості / О. Коропецька // Збірник наукових праць: філософія, соціологія, психологія. - 2011. - Вип. 16 (2). - С. 156-163.

7. Муляр В. І. Проблема становлення особистості в системі «індивід - суспільство» (філософськокультурологічний аналіз): монографія / В. І. Муляр. - Житомир, 2005. - 320 с.

8. Ненько Ю. П. Сутність поняття «творчість», «творча самореалізація» / Ю. П. Ненько // Збірник наукових праць Уманського державного педагогічного університету. - 2009. - Ч. 2. - С. 245-251.

9. Савчук О. П. Педагогічна підтримка особистісної самореалізації майбутніх учителів / О. П. Савчук // Науковий часопис НПУ імені М. П. Драгоманова. - 2010. - Вип. 12 (22). - С. 154-158.

10. Стасенко О. А. Організація фізкультурно-оздоровчої роботи у загальноосвітніх навчальних закладах: шляхи та перспективи / О. А. Стасенко // Молодой ученый. - 2016. - № 9.1 (36.1). - С. 51-156.

11. Шаповалова I. В. Підготовка майбутніх учителів фізичної культури до самовдосконалення та формування основ здорового способу життя: теоретичний аспект / І. В. Шаповалова // Педагогіка формування творчої особистості у вищій і загальноосвітній школах. -2014. - Вип. 36. - С. 427-437.

\section{REFERENCES}

1. Arefieva, L. P. (2010). Pidhotovka maibutnikh uchyteliv fizychnoi kultury do pozaklasnoi vykhovnoi roboty u starshii shkoli [Preparation of the future teachers of the physical culture for extracurricular education work in the high school]. Extended abstract of candidate's thesis. Kiev. [In Ukrainian].

2. Bermudes D. V. Pidhotovka maybutnikh uchyteliv fizychnoyi kul'tury do realizatsiyi variatyvnykh moduliv u protsesi profesiynoyi diyal'nosti [Training future physical education teachers to realize variable modules in their professional activity]. Scientific Journal of Chernihiv National Pedagogical University. Pedagogical sciences. S. 137, 200 - 203s. [In Ukrainian].

3. Vatkovska M. H. Samorealizatsiya osobystosti v postindustrial'nomu suspil'stvi. [Self-realization of an individual in the post-industrial society] Visnyk Natsional'noyi akademiyi kerivnykh kadriv kul'tury i mystetstv.- S.3, 3-8. [In Ukrainian].

4. Denysenko N. H. Pidhotovka maybutnikh uchyteliv fizychnoyi kul'tury do ozdorovchoyi roboty z molodshymy shkolyaramy [Preparation of future teachers of physical culture for improving work with junior school children] Extended abstract of candidate's thesis. Kiev. [In Ukrainian].

5. Ihnatenko, S. O. Pidhotovka maibutnikh uchyteliv fizychnoho vykhovannia do formuvannia moralnykh yakostei molodshykh shkoliariv [Preparation of future teachers of physical education for the formation of moral qualities of junior pupils]. Extended abstract of candidate's thesis. Odessa. [In Ukrainian].

6. Koropetska O. Samorealizatsiya yak ekzystentsiyna potreba osobystosti. [Self-realization as an existential need of a person] Collection of scientific works: philosophy, sociology, psychology. 16(2), 156-163. [In Ukrainian].

7. Muljar V. I. Problema stanovlennya osobystosti v systemi «indyvid - suspil'stvo» (filosofs'ko-kul'turolohichnyy analiz): [monohrafiya], [Issue of identity in the «individual - society» (philosophical and cultural analysis): Monograph], Zhitomir. 320s. [In Ukrainian].

8. Nenko Yu. P. Sutnist'ponyattya «tvorchist'», «tvorcha samorealizatsiya» [The essence of understanding «creativity», «creating self-actualization»] Zbirnyk naukovykh prats' Umans'koho derzhavnoho pedahohichnoho universytetu.- S. 2, 245-251. [In Ukrainian].

9. Savchuk O. P. Pedahohichna pidtrymka osobystisnoyi samorealizatsiyi maybutnikh uchyteliv [Pedagogical support for personal self-realization of future teachers] Naukovyy chasopys NPU imeni M. P. Drahomanova. Scientific Journal of National Pedagogical Dragomanov University. S. 12(22), 154-158. [In Ukrainian].

10. Stasenko O. A. Orhanizatsiya fizkul'turno-ozdorovchoyi roboty u zahal'noosvitnikh navchal'nykh zakladakh: shlyakhy ta perspektyvy. [Organization of sports and health recreation work at institutions of general education: means and prospects] «Young Scientist» S. 9.1 (36.1), 151-156. [In Ukrainian].

11. Shapovalova I. V. Pidhotovka maybutnikh uchyteliv fizychnoyi kul'tury do samovdoskonalennya ta formuvannya osnov zdorovoho sposobu zhyttya: teoretychnyy aspekt. [Preparation of the Future Physical Education Teachers for Self-Improvement and Formation of the Foundations of a Healthy Lifestyle: Theoretical Aspect.] Pedahohika formuvannya tvorchoyi osobystosti u vyshchiy i zahal'noosvitniy shkolakh. S. 36, 427-437.

[In Ukrainian].

Стаття надійшла в редакиію 24.08.2017 p. 